\title{
Ultrastructural alterations in capillaries of the diabetic hypertensive rat retina: protective effects of ACE inhibition
}

\author{
A. A. Dosso ${ }^{1,2}$ - E. Rungger-Brändle ${ }^{1}$ P. M. Leuenberger ${ }^{1}$ \\ ${ }^{1}$ Laboratory of Cell Biology, University Eye Clinic, Geneva, Switzerland \\ ${ }^{2}$ Clinique d'Ophtalmologie, Hôpital cantonal universitaire, Genève, Switzerland
}

\section{Abstract}

Aims/hypothesis. The ACE inhibitor cilazapril was administered to diabetic hypertensive rats to evaluate its ability to influence the development of retinal capillary alterations.

Methods. Normotensive (strain: Wistar Kyoto) and genetically hypertensive (strain: spontaneously hypertensive) rats were rendered diabetic by intravenous injections of streptozotocin. Half of the diabetic animals received cilazapril with their daily food. At 20 weeks of diabetes, endothelial cells, pericytes and extracellular matrix were assessed by ultrastructural morphometry. Each experimental group consisted of seven animals.

Results. Cilazapril normalised systolic arterial pressure in diabetic hypertensive rats $(137 \pm 2 \mathrm{~mm} \mathrm{Hg}$ compared with $188 \pm 16 \mathrm{~mm} \mathrm{Hg}$ in non-medicated diabetic hypertensive rats, $p<0.001)$. The number of endothelial intercellular junctions was reduced in untreated diabetic hypertensive rats $(0.15 \pm 0.05, p<0.02$, vs $0.47 \pm 0.20$ in non-diabetic normotensive rats). In dia- betic hypertensive animals treated with cilazapril, this loss was attenuated $(0.32 \pm 0.16, p<0.05)$. The significant thickening of the basement membrane observed in the diabetic normotensive $(132.8 \pm 19.4 \mathrm{~nm})$ and diabetic hypertensive $(150.3 \pm 20.2 \mathrm{~nm})$ groups was decreased by cilazapril in the diabetic hypertensive group $(116.7 \pm 11.0 \mathrm{~nm}, p<0.01)$, but was unaffected in the normotensive $(131.9 \pm 17.3 \mathrm{~nm})$ group. No protective effect of the drug was observed in either group on pericytes.

Conclusions/interpretation. Long-term administration of an effective antihypertensive therapy normalises endothelial alterations and basement membrane thickness in diabetic hypertensive conditions, and thus may account for the well-known improvement of the blood-retinal barrier observed during antihypertensive treatment.

Keywords ACE inhibitor - Capillaries - Diabetic hypertensive rat $\cdot$ Diabetic retina $\cdot$ Ultrastructural morphometry
Received: 6 January 2004 / Accepted: 19 April 2004

Published online: 9 July 2004

(C) Springer-Verlag 2004

A. A. Dosso (®)

Clinique d'Ophtalmologie,

Hôpital cantonal universitaire,

22, rue Alcide Jentzer, 1211 Genève 14, Switzerland

E-mail: andre.dosso@hcuge.ch

Tel.: +41-22-3838363, Fax: +41-22-73828382

Abbreviations: ANGII, angiotensin II · RAS, renin-angiotensin system $\cdot$ SHR, spontaneously hypertensive rat .

STZ, streptozotocin · VEGF, vascular endothelial growth factor . WKY, Wistar Kyoto

\section{Introduction}

Most diabetic patients will develop diabetic retinopathy $[1,2,3]$ and, despite the beneficial effect of photocoagulation, diabetic retinopathy remains the leading cause of blindness in young adults $[4,5]$. Duration of diabetes $[6,7,8]$, poor blood glucose control [9], and systemic hypertension $[10,11,12,13,14,15]$ are established risk factors for the development of retinopathy and its further progression.

There is little doubt that strict glucose control is essential in the management of diabetic retinopathy. However, another important and, probably decisive in- 
tervention is to normalise blood pressure $[16,17,18]$. Currently, the combination of strict metabolic and blood pressure control is the most promising preventive strategy and should be provided to all diabetic patients.

The mechanisms by which an antihypertensive treatment protects the retina are largely unknown. There is evidence that hypertension induces shear stress, leading, in an initial phase, to hyperplasia of the vascular endothelium and to hypertrophia of its cytoskeleton [19], and later to degenerative processes [20], followed ultimately by the formation of acellular capillaries $[19,20]$. Lowering blood pressure might decrease the shear stress exerted on the vascular wall. However, it has also been claimed that the beneficial action of an antihypertensive drug is not restricted to its hypotensive effect [21, 22, 23]. Indeed, a potential role for the renin-angiotensin system (RAS) in the development of retinopathy has been suggested by the finding that diabetic retinopathy is associated with elevated levels of plasma prorenin and ACE, and with an enhanced prorenin and renin content in the vitreous fluid $[24,25]$. Moreover, renin and ACE, two key enzymes of the metabolic pathway of angiotensin II (ANGII) synthesis, have been localised at the level of the retinal vasculature $[26,27]$. Thus, it is likely that direct inhibition of retinal ACE accounts for the beneficial effect of this kind of systemic antihypertensive treatment on the development of retinopathy $[22$, 28].

Here, we present morphometric data on the effect of the ACE inhibitor cilazapril on the ultrastructure of the capillary wall in the rat retina of the normotensive Wistar Kyoto (WKY) and the spontaneously hypertensive (SHR) strain, both rendered diabetic by streptozotocin (STZ). This study is an extension of previously published data from our laboratory, demonstrating important remodelling of the capillary wall in retinas of non-treated diabetic and hypertensive animals [29]. We present these data for comparison, since the experiments were done concurrently on age-matched siblings.

\section{Materials and methods}

Animals and anaesthesia. All animal care and handling were conducted in accordance with the ARVO Statement for the Use of Animals in Ophthalmic and Vision Research, and with the Swiss Law on Animal Protection.

Spontaneously hypertensive male SHR rats and their normotensive WKY counterparts were purchased from Iffa Credo, Lyon, France. At 7 weeks of age (mean weight $240 \mathrm{~g}$ ), they were rendered diabetic by a single intravenous injection of streptozotocin $(60 \mathrm{mg} / \mathrm{kg}$ body weight; Sigma, Buchs, Switzerland). All animals were kept under identical light conditions on a 14-h light ON and 10-h light OFF cycle and given free access to a normal diet and water, except that half of the diabetic rats of both strains received cilazapril (10 mg/kg body weight) with their daily food for the duration of the experiment. Non- diabetic and untreated SHR and WKY littermates served as controls.

Body weight, glucose levels after an overnight fast, as well as basal glucose levels were determined with a glucose analyser (Beckman Instruments, Zurich, Switzerland) at monthly intervals. Systolic blood pressure was measured monthly in the conscious state, by indirect tail cuff plethysmography. It was also measured immediately before the animals were killed at the end of the study, 20 weeks after induction of diabetes.

Anaesthesia was induced with $2 \%$ isoflurane given into an air stream and maintained with an intraperitoneal injection of pentothal (Abbott, Cham, Switzerland). The animals were killed by intracardiac injection of $1 \mathrm{~mol} / \mathrm{l} \mathrm{KCl}$ before enucleation.

Tissue processing and morphometric measurements. The morphometric study comprised five experimental groups of seven animals each: SHR-D (hypertensive diabetic), SHR-Dt (hypertensive diabetic treated with cilazapril), WKY-N (normotensive non-diabetic), WKY-D (normotensive diabetic), WKY-Dt (normotensive diabetic treated with cilazapril).

Tissue processing, electron microscopy, morphometric measurements and statistics were performed as detailed in a previous study [29]. Briefly, enucleated eyes were immersionfixed in $2.5 \%$ glutaraldehyde in $0.1 \mathrm{~mol} / \mathrm{l}$ cacodylate buffer ( $\mathrm{pH} 7.4$ ) containing $0.2 \%$ tannic acid, washed in the same buffer, and post-fixed in $0.5 \%$ osmium tetroxide. Tissue pieces were block-stained with uranyl acetate, dehydrated through a graded series of ethanol, and embedded in Epon.

Computer-assisted morphometric measurements were done on electron micrographs taken from ten to twelve randomly selected capillaries of the outer plexiform layer from four different tissue blocks of the same retina. Only cross-sectioned capillaries were considered. Thus, a total of up to 84 capillaries per experimental group were evaluated. To assess the caliber of the capillaries, the thickness of the basement membrane, as well as the size and shape of endothelial cells and pericytes, eight different measurements were performed (details, see [29]).

Statistical analysis. The parameters are given as the mean \pm SD. The significance of differences between groups was tested by ANOVA and the Student-Newman-Keuls test [30]. A $p$ value of 0.05 was considered statistically significant. All measurements were carried out in a masked manner without prior knowledge of the capillary's origin.

\section{Results}

Weight, blood glucose and arterial pressure

The metabolic and physical parameters are shown in Table 1 . The mean systolic blood pressure was significantly higher in the diabetic SHR strain $(188 \pm 16 \mathrm{~mm} \mathrm{Hg})$ than in the diabetic WKY strain $(145 \pm 8 \mathrm{~mm} \mathrm{Hg})$. In the SHR group treated with cilazapril, systolic blood pressure was lowered to the normal values seen in the WKY-N group $(135 \pm 13 \mathrm{~mm} \mathrm{Hg})$. However, this antihypertensive treatment had no effect on blood glucose levels in the diabetic animals of either strain (WKY-D, $38.0 \pm 3.1 \mathrm{mmol} / \mathrm{l}$; WKY-Dt, $37.1 \pm 1.8 \mathrm{mmol} / \mathrm{l}$; SHR-D, $40.7 \pm 3.3 \mathrm{mmol} / \mathrm{l}$; SHR-Dt, $39.8 \pm 1.0 \mathrm{mmol} / \mathrm{l})$. 
Table 1. Metabolic and physical parameters of normotensive non-diabetic (WKY-N), normotensive diabetic (WKY-D), treated normotensive diabetic (WKY-Dt). hypertensive diabetic (SHR-D) and treated hypertensive diabetic(SHR-Dt) rats at 27 weeks of age

\begin{tabular}{|c|c|c|c|c|c|c|}
\hline & WKY-N & WKY-D & WKY-Dt & SHR-D & SHR-Dt & $p$ values \\
\hline Basal blood glucose (mmol/l) & $7.0 \pm 1.2$ & $38.0 \pm 3.1$ & $37.1 \pm 1.8$ & $40.7 \pm 3.3$ & $39.8 \pm 1.0$ & $0.001^{\mathrm{a}, \mathrm{b}, \mathrm{c}, \mathrm{d}}$ \\
\hline Fasting blood glucose $(\mathrm{mmol} / \mathrm{l})$ & $5.1 \pm 0.4$ & $18.9 \pm 4.3$ & $15.1 \pm 1.6$ & $20 \pm 4.5$ & $17.9 \pm 4.2$ & $0.001^{\mathrm{a}, \mathrm{b}, \mathrm{c}, \mathrm{d}}$ \\
\hline Systolic blood pressure $(\mathrm{mm} \mathrm{Hg})$ & $135 \pm 13$ & $145 \pm 8$ & $132 \pm 9$ & $188 \pm 16$ & $137 \pm 2$ & $0.001^{\mathrm{c}, \mathrm{e}, \mathrm{f}, \mathrm{g}}$ \\
\hline
\end{tabular}

Values (for seven rats per group) are given as means \pm SD.

a WKY-N compared with WKY-D; b WKY-N compared with

WKY-Dt; ${ }^{c}$ WKY-N compared with SHR-D; ${ }^{\mathrm{d}}$ WKY-N com-

pared with SHR-Dt; e SHR-D compared with SHR-Dt; ${ }^{\text {f SHR-D }}$ compared with WKY-Dt; g SHR-D compared with WKY-D

Table 2. Ultrastructural morphometry of capillaries of the retina in normotensive non-diabetic (WKY-N), normotensive diabetic (WKY-D), treated normotensive diabetic (WKY-Dt), hypertensive diabetic (SHR-D) and treated hypertensive diabetic (SHR-Dt) rats

\begin{tabular}{|c|c|c|c|c|c|c|}
\hline & WKY-N & WKY-D & WKY-Dt & SHR-D & SHR-Dt & $p$ values \\
\hline \multicolumn{7}{|l|}{ Caliber of retinal capillaries } \\
\hline $\begin{array}{l}\text { Inner basement membrane area }\left(\mu \mathrm{m}^{2}\right) \\
\text { Outer basement membrane area }\left(\mu \mathrm{m}^{2}\right)\end{array}$ & $\begin{array}{l}36.5 \pm 5.2 \\
50.2 \pm 8.3\end{array}$ & $\begin{array}{l}41.2 \pm 3.0 \\
55.9 \pm 5.4\end{array}$ & $\begin{array}{l}35 \pm 2.5 \\
49.9 \pm 6.0\end{array}$ & $\begin{array}{l}35.4 \pm 3.3 \\
50.7 \pm 5.1\end{array}$ & $\begin{array}{l}34.7 \pm 5.4 \\
48.2 \pm 6.6\end{array}$ & \\
\hline \multicolumn{7}{|l|}{ Basement membrane } \\
\hline Thickness (nm) & $111.8 \pm 14.2$ & $132.8 \pm 19.4$ & $131.9 \pm 17.3$ & $150.3 \pm 20.2$ & $116.7 \pm 11.0$ & $\begin{array}{l}<0.05^{\mathrm{a}},<0.05^{\mathrm{b}}, \\
<0.005^{\mathrm{c}},<0.01^{\mathrm{e}}\end{array}$ \\
\hline \multicolumn{7}{|l|}{ Endothelial cells } \\
\hline Endothelial cytoplasmic area $\left(\mu \mathrm{m}^{2}\right)$ & $15.6 \pm 2.4$ & $11.5 \pm 3.0$ & $10.1 \pm 2.2$ & $13.0 \pm 3.5$ & $10.9 \pm 4.2$ & $\begin{array}{l}<0.02^{\mathrm{a}},<0.01^{\mathrm{b}}, \\
<0.02^{\mathrm{d}}\end{array}$ \\
\hline $\begin{array}{l}\text { Lumen area }\left(\mu \mathrm{m}^{2}\right) \\
\text { Endothelial pseudopod pair per capillary } \\
\text { Endothelial nuclei per capillary }\end{array}$ & $\begin{array}{l}9.5 \pm 4.8 \\
0.47 \pm 0.20 \\
0.78 \pm 0.12\end{array}$ & $\begin{array}{r}16.1 \pm 1.7 \\
0.30 \pm 0.13 \\
0.79 \pm 0.20\end{array}$ & $\begin{array}{r}12.7 \pm 2.3 \\
0.27 \pm 0.06 \\
0.68 \pm 0.14\end{array}$ & $\begin{array}{r}13.1 \pm 3.0 \\
0.15 \pm 0.05 \\
0.69 \pm 0.23\end{array}$ & $\begin{array}{r}10.8 \pm 3.7 \\
0.32 \pm 0.16 \\
0.66 \pm 0.25\end{array}$ & $\begin{array}{l}<0.05^{\mathrm{a}} \\
<0.02^{\mathrm{c}},<0.05^{\mathrm{e}}\end{array}$ \\
\hline \multicolumn{7}{|l|}{ Pericytes } \\
\hline $\begin{array}{l}\text { Pericyte processes per capillary } \\
\text { Pericyte nuclei per capillary }\end{array}$ & $\begin{array}{l}2.3 \pm 0.7 \\
0.37 \pm 0.10\end{array}$ & $\begin{array}{l}1.7 \pm 0.2 \\
0.24 \pm 0.06\end{array}$ & $\begin{array}{l}2.0 \pm 0.3 \\
0.22 \pm 0.07\end{array}$ & $\begin{array}{l}1.9 \pm 0.3 \\
0.18 \pm 0.12\end{array}$ & $\begin{array}{l}1.7 \pm 1.0 \\
0.23 \pm 0.10\end{array}$ & $\begin{array}{l}<0.02^{\mathrm{a}} \\
<0.04^{\mathrm{a}},<0.02^{\mathrm{b}} \\
<0.02^{\mathrm{c}}\end{array}$ \\
\hline
\end{tabular}

Values are for seven animals per group. a WKY-N compared with WKY-D; ${ }^{b}$ WKY-N compared with WKY-Dt; ${ }^{c}$ WKY-N compared with SHR-D; d WKY-N compared with SHR-Dt;

Morphometric measurements of retinal capillaries

Capillary caliber. Comparing the inner and outer basement area, we noted elevated values specifically in the normotensive diabetic (WKY-D) group $\left(41.2 \pm 3.0 \mu \mathrm{m}^{2}\right.$ and $55.9 \pm 5.4 \mu \mathrm{m}^{2}$ respectively), suggesting a tendency of these vessels to dilate (Table 2). By contrast, all other groups had more and less the same values as the normotensive non-diabetic rats $\left(36.5 \pm 5.2 \mu \mathrm{m}^{2}\right.$ and $50.2 \pm 8.3 \mu \mathrm{m}^{2}$ respectively).

Basement membrane. The most striking alteration in the diabetic animals, readily detectable by electron microscopy, was a pronounced thickening of the basement membrane. Figure 1 shows a cross-section through a retinal capillary of a hypertensive diabetic (SHR-D) rat with a focally thickened extracellular matrix in regions where the endothelial cell is in contact with a Müller glial cell process. e SHR-D compared with SHR-Dt. All comparisons were statistically considered, but only the significant $p$ values are indicated. IBML, inner basement membrane length

Compared with the normotensive non-diabetic controls (WKY-N, $111.8 \pm 14.2 \mathrm{~nm}$ ), both the normotensive (WKY-D, $132.8 \pm 19.4 \mathrm{~nm}, p<0.05$ ) and the hypertensive diabetic (SHR-D, 150.3 $\pm 20.2 \mathrm{~nm}, p<0.005$ ) groups (Table 2) showed a significant increase in thickness in these regions of the basement membrane. This value was fully normalised in the cilazapril-treated hypertensive diabetic rats (SHR-Dt, $116.7 \pm 11.0 \mathrm{~nm}$, $p<0.01)$. Cilazapril did not, however, normalise basement membrane thickness in the normotensive diabetic (WKY-Dt, $131.9 \pm 17.3 \mathrm{~nm}$ ) rats.

Endothelial cells. Counts of the number of nuclear cross-sections did not reveal any loss of endothelial cells in any of the experimental groups. Compared with the controls (WKY-N, 15.6 $\pm 2.4 \mu \mathrm{m}^{2}$ ), a significant decrease of the cytoplasmic area of endothelial cells was noted in the normotensive diabetic (WKY-D, $\left.11.5 \pm 3.0 \mu \mathrm{m}^{2}, p<0.02\right)$ and the cilazapril-treated dia- 


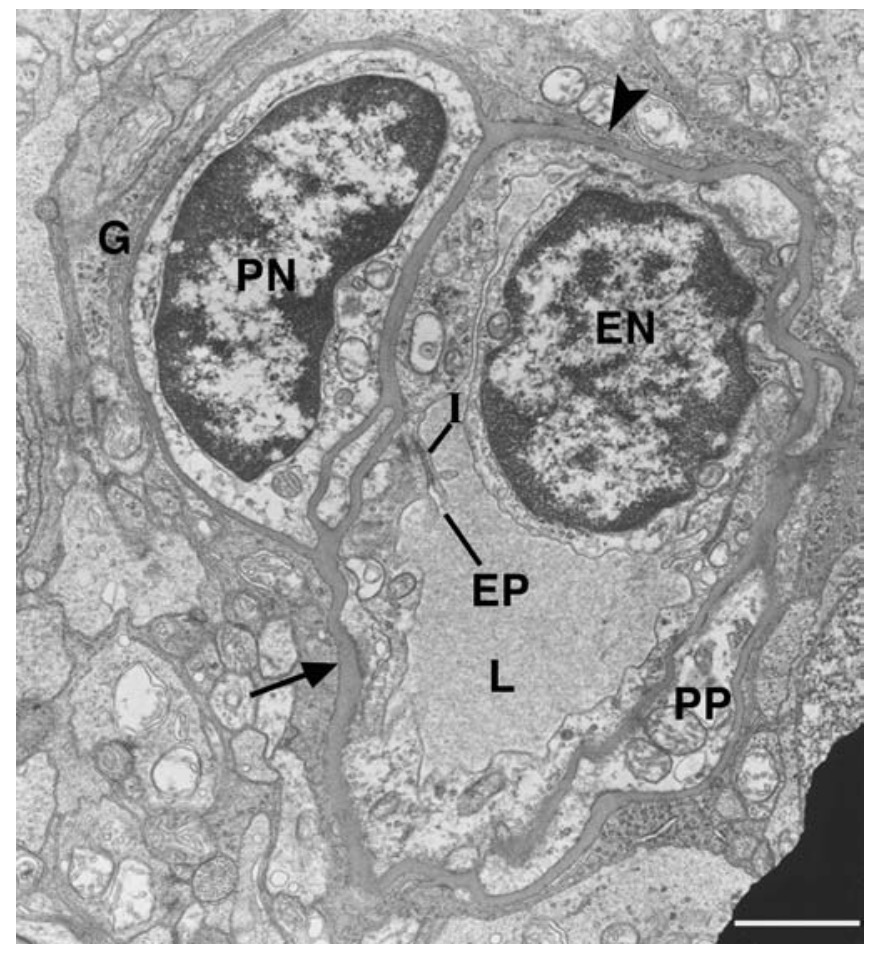

Fig. 1. Electron micrograph of a capillary from the outer plexiform layer of a spontaneously hypertensive, diabetic rat. EN, endothelial cell nucleus; EP, endothelial pseudopod pairs associated with intercellular junction; $G$, glia limitans; I, intercellular junction; L, vessel lumen; PN, pericyte nucleus; PP, pericyte process. The arrowhead denotes the segment of the outer basement membrane, between endothelial cell and glia limitans, that was used to measure basement membrane width. The arrow points to focal thickenings of the basement membrane. Scale bar: $1 \mu \mathrm{m}$

betic groups of both strains (WKY-Dt, $10.1 \pm 2.2 \mu \mathrm{m}^{2}$, $p<0.01$; SHR-Dt, $\left.10.9 \pm 4.2 \mu \mathrm{m}^{2}, p<0.02\right)$. Moreover, in the WKY-D group, the vascular lumen area was significantly enlarged $\left(16.1 \pm 1.7 \mu \mathrm{m}^{2}\right.$ vs $9.5 \pm 4.8 \mu \mathrm{m}^{2}$ in WKY-N, $p<0.05)$, reflecting a marked thinning of the endothelial layer in diabetic animals. A similar, though not significant tendency was observed in the SHR-D group $\left(13.1 \pm 3.0 \mu \mathrm{m}^{2}\right)$. In both cilazapril-treated diabetic groups, however, a tendency to normalise the lumen area was noted (WKY-Dt, $12.7 \pm 2.3 \mu \mathrm{m}^{2}$; SHR-Dt, $10.8 \pm 3.7 \mu \mathrm{m}^{2}$ ).

To estimate the number of intercellular junctions (see Fig. 1), the number of cytoplasmic pseudopod pairs that are regularly associated with intercellular junctions was determined (Table 2). Compared with normotensive non-diabetic animals (WKY-N, $0.47 \pm 0.20$ ), we found a significant reduction in the hypertensive diabetic SHR-D group $(0.15 \pm 0.05, p<0.02)$, reflecting a less intricate shape of the endothelial cells. Cilazapril treatment restored the number of pseudopod pairs in the SHR-Dt $(0.32 \pm 0.16, p<0.05)$ but not in the WKY-Dt group $(0.27 \pm 0.06)$.

Pericytes. In contrast to the endothelial cells, the number of nuclear cross-sections of pericytes was signifi- cantly smaller in the diabetic groups of both strains (WKY-N, 0.37 \pm 0.10 ; WKY-D, 0.24 $\pm 0.06, p<0.04$; SHR-D, $0.18 \pm 0.12, p<0.02)$. This loss was not corrected by cilazapril. The treatment did not influence covering of the endothelial cell by pericyte processes, nor did it influence the number of pericyte processes, indicating that the pericyte shape was not improved.

\section{Discussion}

We found that treatment with the ACE inhibitor cilazapril significantly improved morphological features in retinal capillaries of the hypertensive diabetic rat. Cilazapril normalised the thickness of the basement membrane and the shape of the endothelial cells. However, a complete normalisation was not achieved. Neither did we observe any change in the morphology of the pericytes.

By lowering systemic blood pressure, ACE inhibitors reduce shear stress exerted on the endothelial wall. This makes the endothelial cell the primary target of the treatment, leaving the pericyte virtually unaffected. Indeed, this cellular preference was observed in our study. However, it is likely that the beneficial effect of ACE inhibitors in the retina goes well beyond a general haemodynamic action and intervenes in pathways that specifically relate to signalling of the local RAS controlling autoregulation of the retinal circulation [27]. Indeed, all components of the RAS have been localised in retinal vessels [31, 32, 33, 34, 35], and both impaired RAS [22, 36, 37] and deficient vascular autoregulation [38] have been associated with diabetic retinopathy. In the hypertensive retina, failure in autoregulation may directly transmit elevated systemic blood pressure down to the microcirculation, causing capillary hypertension and eventually structural damage to the endothelial cells. Thus, improvement of retinal autoregulation by ACE inhibitors may contribute to the formation of a haemodynamic milieu capable even of attenuating the progression of diabetic retinopathy [38].

It is possible that ACE inhibitors have other protective functions. For instance, by inhibiting bradykinin degradation, ACE inhibitors promote an increase in nitric oxide and prostacyclin [39]. It has been shown that, through this mechanism, Na,K-ATPase in the retinal vasculature is increased [40] and its activity in the diabetic retina improved [22]. Yet, it remains to be seen whether the functional improvement detected by electroretinography [41] can be directly related to the action of ACE inhibitors on the Na,K-ATPase system. It is also not known to what extent the pathway via $\mathrm{Na}, \mathrm{K}-\mathrm{ATPase}$ has an impact on the morphological features considered in this study.

Most importantly, RAS is also involved in growth factor expression, in particular of vascular endothelial growth factor (VEGF) and TGF-beta. Indeed, in- 
creased VEGF expression in the diabetic rat [42] can be normalised by ACE inhibition [43, 44]. Moreover, TGF-beta signalling contributes substantially to the turnover of the extracellular matrix [45]. In the presence of high glucose, angiotensin II has been shown to stimulate secretion of TGF-beta [46] and to increase matrix accumulation [47] by activating the synthesis of collagen I [48] and fibronectin [49] and by decreasing matrix degradation [50]. Thus, the blockage of angiotensin II formation by ACE inhibitors decreases the expression of TGF-beta, reduces the accumulation of matrix protein synthesis [51], and accelerates its degradation $[52,53]$. In line with these observations, the significant reduction in the thickness of retinal capillary basement lamina that we observed after treatment with captopril may be mediated by TGFbeta. Indeed, in an ongoing study we are now testing the extent to which TGF-beta is engaged in the pathogenesis of retinopathy.

The selectivity of the endothelial cell as a target of ACE inhibitors noted in vivo in this study and in [54] and in vitro $[41,54]$ may explain why excessive leakage of the blood-retinal barrier in patients [21,23] and diabetic animals [43] was prevented by long-term treatment. Yet, it remains to be seen why no improvement of the capillary parameters considered in our experiments were found in the normotensive diabetic group. It is likely that the threshold levels of the numerous triggers, as well as the complexity and activity of the various signalling pathways involved, differ in the hyperglycaemic, the hypertensive, and the combined condition. These differences may result, at least in part, in different levels of responsiveness to a particular drug.

In conclusion, our observations show that the longterm administration of cilazapril not only decreases systolic arterial pressure to near normal levels, but also prevents basement membrane thickening and alterations of the endothelial cell in the hypertensive diabetic animal. Whether this benefit is achieved exclusively through the lowering of blood pressure or by other mechanisms remains to be clarified. In accordance with clinical studies [16, 17, 18], our observations support recommendations that systemic blood pressure be strictly controlled.

Acknowledgements. This study was supported by Swiss National Science Foundation, Grant 32-39372.93, and Roche Pharma, Switzerland. The authors thank Sabina Scarpino, Alain Conti and Nicole Gilodi for skillful technical assistance.

\section{References}

1. Klein R, Klein BEK, Moss SE (1984) Visual impairment in diabetes. Ophthalmology 91:1-9

2. Orchard TJ, Dorman JS, Maser RE et al. (1990) Prevalence of complications in IDDM by sex and duration. Pittsburgh Epidemiology of Diabetes Complications Study II. Diabetes 39:1116-1124
3. Dwyer MS, Melton LJ, Ballard DJ, Palumbo PJ, Trautmann JC, Chu CP (1985) Incidence of diabetic retinopathy and blindness: a population-based study in Rochester, Minnesota. Diabetes Care 8:316-322

4. Moss SE, Klein R, Klein BE (1988) The incidence of vision loss in a diabetic population. Ophthalmology 95:1340-1348

5. Porta M, Tomalino MG, Santoro F, Ghigo LD, Cairo M, Aimone M (1995) Diabetic retinopathy as a case of blindness in the province of Turin, north-west Italy, in 1967-1991. Diabetic Med 12:355-361

6. Klein R, Klein BEK, Moss SE, Davis MD, DeMets DL (1984) The Wisconsin epidemiologic study of diabetic retinopathy. II. Prevalence and risk of diabetic retinopathy when age at diagnosis is less than 30 years. Arch Ophthalmol 102:520-526

7. Klein R, Klein BEK, Moss SE, Davis MD, DeMets DL (1984) The Wisconsin epidemiologic study of diabetic retinopathy. II. Prevalence and risk of diabetic retinopathy when age at diagnosis is 30 or more years. Arch Ophthalmol 102:527-532

8. Klein R, Klein BEK, Moss SE (1992) Epidemiology of proliferative diabetic retinopathy. Diabetes Care 15:1875-1891

9. Control and Complications Trial Research Group (DCCT) (1993) The effect of intensive treatment of diabetes on the development and progression of long-term complications in insulin-dependent diabetes mellitus. $N$ Engl J Med 329:977-986

10. Teuscher A, Egger M, Herman JB (1989) Diabetes and hypertension: blood pressure in clinical diabetic patients and a control population. Arch Intern Med 149:1942-1945

11. Klein R, Klein BEK, Le KE, Cruickshanks KJ, Moss SE (1996) The incidence of hypertension in insulin-dependent diabetes. Arch Intern Med 156:622-627

12. Parving H-H (1991) Impact of blood pressure and antihypertensive treatment on incipient and overt nephropathy, retinopathy, and endothelial permeability in diabetes mellitus. Diabetes Care 14:260-269

13. Janka HU, Ziegler AG, Valsania P, Warram JH, Krolewski AS (1989) Impact of blood pressure on diabetic retinopathy. Diabetes Metab 15:333-337

14. Klein BEK, Klein R, Moss SE, Palta M (1995) A cohort study of the relationship of diabetic retinopathy to blood pressure. Arch Ophthalmol 113:601-606

15. Weidmann P, Böhlen LM, de Courten M (1993) Pathogenesis and treatment of hypertension associated with diabetes mellitus. Am Heart J 125:1498-1513

16. Parving $\mathrm{H}-\mathrm{H}$, Larsen $\mathrm{M}$, Hommel E, Lund-Andersen $\mathrm{H}$ (1989) Effect of antihypertensive treatment on bloodretinal barrier permeability to fluorescein in hypertensive Type 1 (insulin-dependent) diabetic patients with background retinopathy. Diabetologia 32:440-444

17. Gin T, Joon TL, Panagiotopoulos S, Cooper M, Taylor H, Jerums G (1996) Organ specificity of antihypertensive therapy on ocular albumin vascular clearance and albuminuria in the hypertensive diabetic rat. Invest Ophthalmol Vis Sci 37:281-289

18. UK Prospective Diabetes Study Group (1998) Efficacy of atenolol and captopril in reducing risk of macrovascular and microvascular complications in type 2 diabetes: UKPDS 39. BMJ 317:713-720

19. Satcher R, Dewey CF Jr, Hartwig JH (1997) Mechanical remodeling of the endothelial surface and actin cytoskeleton induced by fluid flow. Microcirculation 4:439-453

20. Hansen-Smith F, Greene AS, Cowley AW, Lombard JH (1990) Structural changes during microvascular rarefaction in chronic hypertension. Hypertension 15:922-928 
21. Larsen M, Hommel E, Parving H-H, Lund-Andersen $\mathrm{H}$ (1990) Protective effect of captopril on the blood-retinal barrier in normotensive insulin-dependent diabetic patients with nephropathy and background retinopathy. Graefes Arch Clin Exp Ophthalmol 228:505-509

22. Ottlez A, Bensaoula T (1996) Captopril ameliorates the decreased $\mathrm{Na}^{+}, \mathrm{K}^{+}$-ATPase activity in the retina of streptozotocin-induced diabetic rats. Invest Ophthalmol Vis Sci 37:1633-1641

23. Chaturvedi N, Sjolie A-K, Stephenson JM, the EUCLID Study Group (1998) Effect of lisinopril on progression of retinopathy in normotensive people with type 1 diabetes. Lancet 351:28-31

24. Danser AHJ, van den Dorpel MA, Deinum J et al. (1989) Renin, prorenin, and immunoreactive renin in vitreous fluid from eyes with and without diabetic retinopathy. J Clin Endocrinol Metab 68:160-167

25. Schalekamp MADH (1993) Renin-angiotensin system components and endothelial proteins as markers of diabetic microvascular disease. Clin Invest 71:S3-S6

26. Ferrari-Dileo G, Davis EB, Anderson DR (1987) Angiotensin binding sites in bovine and human retinal blood vessels. Invest Ophthalmol Vis Sci 28:1747-1751

27. Brown SM, Jampol LM (1996) New concepts of regulation of retinal vessel tone. Arch Ophthalmol 114:199-204

28. Ottlez A, Garcia CA, Eicheberg J, Fox DA (1993) Alterations in retinal $\mathrm{Na}^{+}, \mathrm{K}^{+}$-ATPase in diabetes: Streptozotocin-induced and Zucker diabetic fatty rats. Curr Eye Res 12:1111-1121

29. Dosso AA, Leuenberger PM, Rungger-Brändle E (1999) Remodeling of retinal capillaries in the diabetic hypertensive rat. Invest Ophthalmol Vis Sci 40:2405-2410

30. Sachs L (1992) Angewandte Statistik. 7th edn. Springer, Berlin Heidelberg

31. Berka JL, Stubbs AJ, Wang DZ et al. (1995) Renincontaining Muller cells of the retina display endocrine features. Invest Ophthalmol Vis Sci 36:1450-1458

32. Kohler K, Wheeler-Schilling T, Jurklies B, Guenther E, Zrenner E (1997) Angiotensin II in the rabbit retina. Vis Neurosci 14:63-71

33. Murata M, Nakagawa M, Takahashi S (1997) Angiotensinogen mRNA is synthesized locally in rat ocular tissues. Ophthalmologica 211:301-304

34. Wagner J, Jan Danser AH, Derkx FH et al. (1996) Demonstration of renin mRNA, angiotensinogen mRNA, and angiotensin converting enzyme mRNA expression in the human eye: evidence for an intraocular renin-angiotensin system. Br J Ophthalmol 80:159-163

35. Gilbert RE, Krumt H, Wilkinson-Berka J, Kelly DJ (2003) The renin-angiotensin system and the long-term complications of diabetes: pathophysiological and therapeutic considerations. Diabet Med 20:607-621

36. Sinclair SH, Grunwald JE, Riva C, Braunstein SL, Nichols CW, Schwartz S (1982) Retinal vascular autoregulation in diabetes mellitus. Ophthalmology 89:748-750

37. Ottlez A, Bensaoula T, Eichberg J, Peterson RG (1996) Angiotensin-converting enzyme activity in retinas of streptozotocin-induced and zucker diabetic rats. Invest Ophthalmol Vis Sci 37:2157-2164

38. Patel V, Rassam SMB, Chen HC, Jones M, Kohner EM (1998) Effect of angiotensin-converting enzyme inhibition with perindopril and b-blockade with atenolol on retinal blood flow in hypertensive diabetic subjects. Metabolism 47:28-33

39. Luetscher JA, Kreamer FB, Wilson DM (1989) Prorenin and vascular complications of diabetes. Am J Hypertens 2:382-386

40. Gupta S, Sussman I, MacArthur CS, Tornheim K, Cohen RA, Ruderman NB (1992) Endothelium-dependent inhibition of $\mathrm{Na}^{+}, \mathrm{K}^{+}$-ATPase activity in rabbit aorta by hyperglycemia. J Clin Invest 90:727-732

41. Bui BV, Armitage JA, Tolcos M, Cooper ME, Vingrys AJ (2003) ACE inhibition salvages the visual loss caused by diabetes. Diabetologia 46:401-408

42. Gilbert RE, Vranes D, Berka JL et al. (1998) Vascular endothelial growth factor and its receptors in control and diabetic rats eyes. Lab Invest 78:1017-1027

43. Gilbert RE, Kelly DJ, Cox AJ et al. (2000) Angiotensin converting enzyme inhibition reduces retinal overexpression of vascular endothelial growth factor and hyperpermeability in experimental diabetes. Diabetologia 43:13601367

44. Moravski CJ, Skinner SL, Stubbs AJ et al. (2003) The renin-angiotensin system influences ocular endothelial cell proliferation in diabetes. Am J Pathol 162:151160

45. Blobe CB, Schiemann WP, Lodish HF (2000) Role of transforming growth factor-beta in human disease. N Engl J Med 342:1350-1360

46. Ziyadeh FN, Sharma K, Ericksen M, Wolf G (1994) Stimulation of collagen gene expression and protein synthesis in murine mesangial cells by high glucose is mediated by autocrine activation of transforming growth factor-beta. J Clin Invest 93:536-542

47. Kagami S, Border WA, Miller DE, Noble NA (1994) Angiotensin II stimulates extracellular matrix protein synthesis through induction of transforming growth factor-beta expression in rat glomerular mesangial cells. J Clin Invest 93:2431-2437

48. Wolf G, Haberstroh U, Neilson EG (1992) Angiotensin II stimulates the proliferation and biosynthesis of type I collagen in cultured murine mesangial cells. Am J Pathol 140:95-107

49. Ray PE, Bruggeman LA, Horikoshi S, Aguilera G, Klotman PE (1994) Angiotensin II stimulates human fetal mesangial cell proliferation and fibronectin biosynthesis by binding to AT1 receptors. Kidney Int 45:177-184

50. Singh R, Alavi N, Singh AK, Leehey DJ (1999) Role of angiotensin II in glucose-induced inhibition of mesangial matrix degradation. Diabetes 48:2066-2073

51. Nakamura T, Takahashi T, Fukui M et al. (1995) Enalapril attenuates increased gene expression of extracellular matrix components in diabetic rats. J Am Soc Nephrol 5:1492-1497

52. Kalender B, Ozturk M, Tuncdemir M et al. (2002) Renoprotective effects of valsartan and enalapril in STZ-induced diabetes in rats. Acta Histochem 104:123-130

53. Volpini RA, da Silva CG, Costa RS, Coimbra TM (2003) Effect of enalapril and losartan on the events that precede diabetic nephropathy in rats. Diabetes Metab Res Rev 19:43-51

54. Zhang J-Z, Gao L, Widness M, Xi X, Kern TS (2003) Captopril inhibits glucose accumulation in retinal cells in diabetes. Invest Ophthalmol Vis Sci 44:4001-4005 